Monika Pawlowska

Artur Stefański

Wyższa Szkoła Bankowa w Poznaniu, Wydzial Finansów i Bankowości

\title{
Analiza wpływu rolników jako grupy kredytobiorców na rentowność i bezpieczeństwo banków spółdzielczych w Polsce w latach 2012-2017
}

\author{
THE ANALYSIS OF THE INFLUENCE FARMERS, \\ AS DEBTORS, HAVE ON THE PROFITABILITY \\ AND SOLVENCY OF COOPERATIVE BANKS \\ IN POLAND BETWEEN 2012-2017
}

Głównym celem artykulu jest ocena znaczenia rolników jako kredytobiorców oraz wpływu tej grupy klientów na rentowność $i$ bezpieczeństwo banków spółdzielczych $w$ Polsce $w$ latach 2012-2017. Analize oparto na danych kwartalnych z okresu od grudnia 2012 do czerwca 2017 roku (19 obserwacji).

Postawiono nastęujace hipotezy: udzial rolników $w$ strukturze kredytów banków spóldzielczych maleje (H1), spadek udziału kredytów dla rolników w kredytach ogótem w bankach spółdzielczych powoduje spadek rentowności, mierzony wskaźnikiem ROA, a siła tej korelacji jest co najmniej umiarkowana (H2), spadajacy udziat rolników w portfelu kredytowym banków spółdzielczych jest dodatnio skorelowany z poziomem łacznego współczynnika wypłacalności oraz wspótczynnika kapitatowego Tier-1 i że jest to korelacja co najmniej o umiarkowanej sile (H3).

Przeprowadzone badania pozwalaja na wysunięcie następujacych wniosków: udziat kredytów dla rolników $w$ tacznym portfelu kredytowym $w$ bankach spótdzielczych $w$ Polsce spada, jest on skorelowany z poziomem rentowności aktywów, korelacja jest dodatnia, a jej siła co najmniej umiarkowana, jednocześnie jest ujemnie skorelowany z poziomem współczynnika wypłacalności oraz współczynnika kapitałowego Tier-1. Zatem pozytywnie zweryfikowane zostały dwie z trzech postawionych hipotez.

Słowa kluczowe: banki spółdzielcze, rolnicy, rentowność, wypłacalność

\section{Wprowadzenie}

W ciagu ostatnich lat banki spółdzielcze uległy znaczącym przemianom. Z klasycznych podmiotów depozytowo-kredytowych przeobraziły się w dynamicznie działające konsorcja, funkcjonujące w każdym obszarze rynku finansowego oraz posiadające szeroką gamę świadczonych usług bankowych. Głównym celem artykułu jest ocena znaczenia rolników jako kredytobiorców dla banków spółdzielczych oraz wpływu tej grupy klientów na rentowność i bezpieczeństwo banków spółdzielczych w Polsce w latach 2012-2017. 
Bankowość spółdzielcza podlegała w ostatnich latach silnym przeobrażeniom strukturalnym, prognozuje się, że te zmiany będą nadal zachodziły intensywnie. Banki spółdzielcze zmieniły swój profil z niszowego, skierowanego głównie do rolników i rzemiosła, na uniwersalny o bardziej zdywersyfikowanej ofercie produktowej ${ }^{1}$. Członkostwo w UE spowodowało dostęp do nowych źródeł finansowania działalności rolniczej, jednocześnie ograniczyło protekcjonizm kredytowy. To wpłynęło na strukturę źródeł finansowania, relatywnie zmniejszyło rolę kredytów bankowych w finansowaniu rolnictwa. Tym samym banki spółdzielcze, które najczęściej kredytowały rolników poszukują innych grup klientów, w których lokują swoje kapitały, stąd hipoteza (H1), że udział rolników w strukturze kredytów banków spółdzielczych maleje.

Poszukiwanie nowej grupy klientów przez banki spółdzielcze związane jest z przygotowywaniem szerszej produktowo oferty, tym samym oczekiwać można zdynamizowania dochodów innych niż odsetkowe. Zmniejszenie udziału kredytowania rolników, dla których kredyty są wyżej dochodowe, powoduje obniżenie wyniku odsetkowego, przyczynia się również w konsekwencji do obniżenia wyniku netto banków. Spadek ten przy rozszerzeniu oferty produktowej powinien być częściowo kompensowany innymi przychodami, niemniej jednak trudno oczekiwać, że uda się ten uszczerbek zrekompensować w pełni, dlatego przyjmuje się hipotezę (H2), że spadek udziału kredytów dla rolników w kredytach ogółem w bankach spółdzielczych powoduje obniżenie rentowności tych banków, mierzonej wskaźnikiem ROA, a siła tej korelacji jest co najmniej umiarkowana.

Zakładany zmniejszający się udział kredytów dla rolników, które cechują się wysoką jakością portfela kredytowego i zwykle wyższą rentownością wynikającą ze stosowanych marż odsetkowych, w portfelu kredytowym banków spółdzielczych, wpływa na pogorszenie rentowności działalności banków. Z jednej strony może to mieć swój wyraz we wzroście kosztów tworzonych rezerw celowych, ponieważ kredyty dla rolników cechują się relatywnie lepszą jakością od przeciętnej w portfelu banków spółdzielczych. Z drugiej strony, pogorszenie rentowności może nastąić również wskutek stosowania niższych marż odsetkowych wobec klientów innych niż rolnicy, co jest choćby konsekwencją próby pozyskiwania tych innych grup klientów kredytowych. Zmniejszenie wyniku netto banków spółdzielczych, który jest elementem funduszy własnych, bezpośrednio wpływa na poziom ich finansowego bezpieczeństwa. Stąd teza, że spadający udział rolników w portfelu kredytowym banków spółdzielczych jest dodatnio skorelowany $\mathrm{z}$ poziomem łącznego współczynnika wypłacalności oraz współczynnika kapitałowego Tier-1 (H3) i że jest to korelacja co najmniej o umiarkowanej sile.

\footnotetext{
${ }^{1}$ S. Kozak: Ewolucje strukturalne w sektorze banków spółdzielczych w latach 1996-2011. Zeszyty Naukowe Uniwersytetu Przyrodniczo-Humanistycznego w Siedlcach, nr 96, Siedlce 2013, s. 126-127; R. Kata: Bankowa obsługa rolnictwa w kontekście zmian modelu funkcjonowania bankowości spółdzielczej w Polsce. Roczniki Naukowe Stowarzyszenia Ekonomistów Rolnictwa i Agrobiznesu, t. XVII, z. 4, Warszawa 2015, s. 129-130.
} 


\section{Rolnicy jako specyficzna grupa klientów banków spółdzielczych}

Konkurencja na rynku bankowym jest coraz większa, dodatkowo rośnie zagrożenie ze strony placówek niebankowych, które oferują produkty zamienne, przez co można uznać problem konkurencyjności za narastający ${ }^{2}$. W bankowości szczególnie ważną pozycję zajmują klienci, to od ich satysfakcji zależy pozycja rynkowa banku ${ }^{3}$. Klienci są postrzegani za wyjątkowy zasób banku. Ich kapitał w banku spółdzielczym ma szczególne znaczenie i wpływa na działalność tych instytucji. Bliskie relacje z klientami, dobre rozeznanie ich potrzeb wynikają z lokalnego charakteru banków spółdzielczych. Dodatkowo klienci banków spółdzielczych często są współwłaścicielami banku, z usług którego korzystają, dlatego zainteresowani są kondycją finansową i rozwojem banków spółdzielczych podwójnie - jako klienci oraz jako właściciele. Banki spółdzielcze chętnie deklarują, iż zysk nie jest ich głównym celem działalności, tylko relacyjny charakter związków z klientami, co sprzyja tworzeniu wizerunku instytucji wartych zaufania. Jednocześnie warto zaznaczyć, że banki spółdzielcze mogą łatwo stracić zaufanie i dobrą reputację przez poszerzanie skali działania poza zasięg lokalny. Szybko w ten sposób mogą stracić bliskie relacje z klientami, działając w ten sam sposób jak banki komercyjne, zatracając swój unikatowy, lokalny charakter ${ }^{4}$.

Lojalność i homogeniczność klientów banków spółdzielczych są elementami tworzącymi ich przewagę konkurencyjną, ale też powodują, że banki te są uzależnione od swoich klientów. Jednorodność interesantów depozytowych powoduje brak różnicowania źródeł finansowania aktywności banku, natomiast ze względu na niezróżnicowanych klientów - kredytobiorców nie dochodzi do dywersyfikacji ryzyka kredytowego w banku spółdzielczym. Niemniej jednak klienci lojalni są bardziej rentowni dla banku. Często klient usatysfakcjonowany staje się klientem aktywnym, który chętniej korzysta $\mathrm{z}$ oferty banku, wobec tego staje się klientem rentownym i mniej skłonnym do wyboru konkurencji ${ }^{5}$.

We współczesnej gospodarce rynkowej korzystanie przez rolników, a także gospodarstwa rolne, z obsługi bankowej i dostępu do finansowania zewnętrznego jest nieodzownym elementem ich stabilności finansowej i rozwoju. Głównym celem relacji rolników z bankami jest chęć alokacji osiagniętej nadwyżki finansowej, czy też pozyskanie zewnętrznych źródeł finansowania działalności rolniczej. Jednocześnie rolnicy będący nabywcami produktów i usług bankowych trafiają na szereg barier i ograniczeń, pośród których wiele jest specyficznych dla sektora rolnego. Aktywa jakimi dysponują i którymi zarządzają rolnicy są nieelastyczne i indywidualne dla danego gospodarstwa. Również charakter produkcji rolnej uzależniony jest w dużym stopniu od

\footnotetext{
2 A. Nowakowska-Krystman, B. Kublik: Strategia rozwoju sektora polskich banków spółdzielczych, w: Perspektywy rozwoju bankowości spółdzielczej w Polsce, red. M. Stefański. Wyższa Szkoła HumanistycznoEkonomiczna we Włocławku, Włocławek 2009, s. 34.

${ }^{3}$ P. Snarski: Metody pomiaru satysfakcji klientów bankowych wykorzystywanych do analizy konkurencyjności banków. Oficyna Wydawnicza Politechniki Białostockiej, Białystok 2012, s.992.

${ }^{4}$ G. Woźniewska: Analiza potencjału konkurencyjnego banku spółdzielczego - zarys koncepcji. Annales Universitatis Mariae Curie-Skłodowska, Sectio H Oeconomia, UMCS, Lublin 2010, s. 330-331.

${ }^{5}$ A. Szelągowska: Współczesna bankowość spółdzielcza. CeDeWu Sp. z o.o., Warszawa 2012, s. 110-111.
} 
okoliczności przyrodniczych. Gospodarstwa rolne charakteryzują się dużym zróżnicowaniem co do wariantu prowadzonej działalności, jak i kapitałochłonności ${ }^{6}$.

Rolnicy jest to segment klientów, któremu banki oferują swoje produkty, należycie dobrane do ich potrzeb. Rolnicy najczęściej korzystają z usług banków spółdzielczych, dla większości z nich są one jedynym bądź najistotniejszym bankiem w zakresie obsługi finansowej. W dużym stopniu o powiązaniach rolników z bankami spółdzielczymi decydują uwarunkowania mikroekonomiczne gospodarstw rolnych, w tym społecznoosobowe. Indywidualny charakter rolnictwa i obszarów wiejskich, ma bezwzględne znaczenie przy doborze oferty produktów i usług bankowych, które odnoszą się do podmiotów znajdujących się na terenach wiejskich ${ }^{7}$. Rozpoznanie aktualnych i późniejszych potrzeb rolników, staje się coraz istotniejszą kwestią. W następstwie tego banki są zobowiązane cały czas analizować rynek, aby produkty i usługi, które proponują rolnikom, realizowały ich oczekiwania i były konkurencyjne ${ }^{8}$.

\section{Wyniki badań oraz ich omówienie}

Wzmocnienie rolnictwa i obszarów wiejskich $w$ Polsce jest jednym $\mathrm{z}$ najistotniejszych wyzwań dla gospodarki narodowej, a tym samym dla banków spółdzielczych oraz innych podmiotów angażujących się w finansowanie rolnictwa ${ }^{9}$. Kredytowanie w rolnictwie jest uznawane za niezbędne do wspierania rozwoju obszarów wiejskich, skutecznej alokacji kapitału i potęgowania skłonności do inwestowania przez rolników. Znaczenie kredytów w rolnictwie zaczęło szybko wzrastać w wyniku liberalizacji gospodarki oraz przyłączenia się Polski do Unii Europejskiej, przez co wzmocniły się stosunki gospodarstw rolnych $\mathrm{i}$ innych podmiotów wiejskich $\mathrm{z}$ gospodarką finansową. Powolne gromadzenie kapitałów własnych niejednokrotnie były niedostateczne, aby dokonać całkowitej modernizacji rolnictwa ${ }^{10}$.

Kredyty dla rolnictwa udzielane są głównie przez banki spółdzielcze, które posiadają jedną $\mathrm{z}$ najlepiej rozwiniętych sieci oddziałów bankowych $\mathrm{w}$ Polsce. Funkcjonują one na rynkach lokalnych, obsługując przeważnie sektor rolnictwa, czy też drobną przedsiębiorczość. Banki spółdzielcze działając w pobliskich okolicach gospodarstw rolnych są naturalnym partnerem finansowym rolników ${ }^{11}$. Zapotrzebowanie na kredyty w rolnictwie wynika głównie z wahań dochodów, spowodowanych m.in.

\footnotetext{
${ }^{6}$ R. Kata: Korzystanie z usług bankowych przez rolników indywidualnych w Polsce. Journal of Agrobusiness and Rural Development, nr 4(22), Uniwersytet Rzeszowski, Rzeszów 2011, s. 87-88.

7 A. Rosa: Korzystanie z usług bankowych przez rolników pomorza środkowego. Roczniki Naukowe Stowarzyszenia Ekonomistów Rolnictwa i Agrobiznesu nr 6, z. 6, Politechnika Koszalińska, Koszalin 2016, s. 415-416.

${ }^{8}$ R. Kata: Bankowa obsługa rolnictwa w kontekście zmian modelu funkcjonowania bankowości spółdzielczej w Polsce. Roczniki Naukowe Stowarzyszenia Ekonomistów Rolnictwa i Agrobiznesu, t. XVII, z. 4, Warszawa 2015, s. 127.

${ }^{9}$ T. Siudek: Wpływ kredytów rolniczych udzielanych przez banki spółdzielcze na rozwój rolnictwa w Polsce. Zeszyty Naukowe SGGW w Warszawie, Ekonomika i Organizacja Gospodarki Żywnościowej, Warszawa 2008, s. 37-38

${ }^{10}$ T. Siudek: Banki spółdzielcze jako instytucje kredytujące rozwój rolnictwa i obszarów wiejskich w Polsce. Zeszyty Naukowe Akademii Rolniczej we Wrocławiu nr 540, Wrocław 2006, s. 47.

${ }^{11}$ R. Kata: Relacje rolników z instytucjami w aspekcie finansowania gospodarstw ze źródeł zewnętrznych, w: Konkurencyjność podmiotów rynkowych, red. D. Kopycińska. Uniwersytet Szczeciński, Szczecin 2009,s. 125127 .
} 
następstwem warunków atmosferycznych. Ponadto popyt na kredyty w rolnictwie wzrasta w momencie występowania niezgodności między okresem poniesionych nakładów na produkcję, a okresem osiągniętych dochodów ${ }^{12}$.

Reasumując, kredyt bankowy pozostaje najważniejszym źródłem zewnętrznego finansowania gospodarstw rolnych, a niezwykle istotnym jest zagwarantowanie rolnikom swobodnego dostępu do tego źródła finansowania gospodarstwa. Inaczej mówiąc banki spółdzielcze oferują rolnikom takie warunki kredytowania, które nie dyskryminują ich oraz nie ograniczają im korzystania z tego typu źródła finansowania. Szczególnie warto zwrócić uwagę, iż w ostatnich latach wzrosła wartość kredytów bankowych udzielonych przez banki spółdzielcze rolnikom, co powinno być odczytywane jako pozytywny symptom, ponieważ wydatki inwestycyjne generują przyrost produkcji w późniejszych okresach ${ }^{13}$. Jednak w tym samym czasie banki spółdzielcze rozwijały także portfel kredytowy dla innych niż rolnicy grup klientów. Wykres 1 prezentuje udział kredytów bankowych udzielonych przez banki spółdzielcze w Polsce rolnikom, na tle innych grup klientów tych banków wydzielonych ze względu na podmiot, w latach 2012-2017, dane kwartalne.

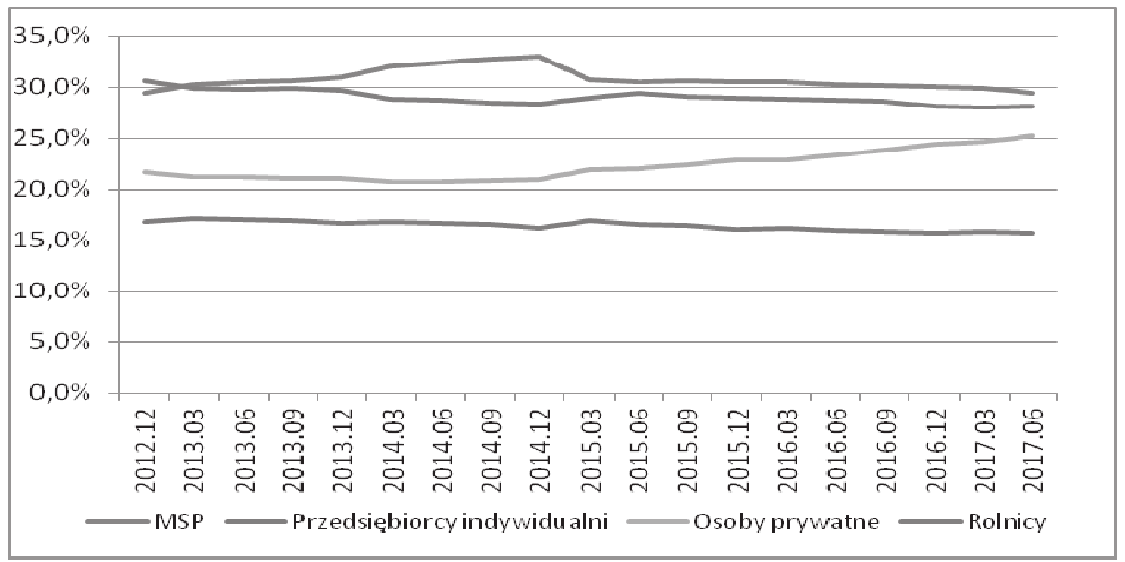

Wykres 1. Struktura należności od klientów niefinansowych w bankach spółdzielczych w Polsce w latach 2012-2017 (w\%)

Źródło: opracowanie własne na podstawie informacji o sytuacji banków spółdzielczych i zrzeszających się w latach 2012-2017, http://www.knf.gov.pl/index.html, [dostęp: 31.10.2017]

Wartość udzielonych kredytów, w tym także kredytów dla rolników w badanym okresie generalnie wzrasta. W analizowanym okresie kredyty dla rolników wzrosły o ok. 3 mld zł, tj. o ok. 20\%. Wolumen kredytów dla rolników w bankach spółdzielczych zwiększa się w tempie porównywalnym do zmian w zakresie kredytów dla przedsiębiorców indywidualnych $(22 \%)$. Najsprawniej wzrastają wartości udzielonych

${ }^{12}$ R. Kata: Kredyty bankowe w strukturze zewnętrznych źródeł finansowania rolnictwa w Polsce. Zeszyty Naukowe SGGW w Warszawie, Problemy Rolnictwa Światowego, t. XXIII, Warszawa 2009, s. 85-86.

${ }^{13}$ M. Utzig: Korzystanie z rynku depozytowo-kredytowego przez rolników w Polsce, Roczniki Ekonomii Rolnictwa i Rozwoju Obszarów Wiejskich, t. 99, z. 4, Warszawa 2012, s. 422-423. 
kredytów osobom prywatnym, tj. 52\%, podczas gdy cały portfel przyrasta w tempie $31 \%$. Można zatem zauważyć, że dynamika portfela kredytów dla rolników jest niższa od dynamiki portfeli kredytowych dla wielu innych grup klientów, a także całego portfela kredytowego banków spółdzielczych, co musiało obniżyć znaczenie portfela kredytów dla rolników w działalności kredytowej banków spółdzielczych w Polsce w analizowanym czasie. Pomimo, iż wartość portfela kredytów rolniczych w bankach spółdzielczych w badanym okresie wzrastała, to ich udział w łącznym wolumenie należności od klientów niefinansowych banków spółdzielczych spada z poziomu $31 \% \mathrm{~W}$ roku 2012, do 28\% w roku 2017. Fakt ten spowodował, że rolnicy przestali być dominującą grupą w podmiotowej strukturze kredytów w bankach spółdzielczych. Sytuacja ta utrzymuje się od I kwartału 2013 roku.

Na potrzeby niniejszego artykułu w celu weryfikacji hipotez $\mathrm{H} 2$ oraz $\mathrm{H} 3$, ustalono związek statystyczny odpowiednio między udziałem rolników w portfelu kredytowym w bankach spółdzielczych a rentownością aktywów oraz wypłacalnością banków spółdzielczych w Polsce w latach 2012-2017. Zastosowano współczynnik korelacji liniowej Pearsona, zbadano też jego statystyczną istotność (przyjęto próg istotności statystycznej 0,05 oraz 17 stopni swobody). Analizę oparto na danych kwartalnych zawartych w tabeli 1 - począwszy od ostatniego kwartału roku 2012 do II kwartału roku 2017, łącznie 19 obserwacji.

Tabela 1. Rentowność aktywów, łączny współczynnik wypłacalności i współczynnik wypłacalności Tier-1 oraz udział rolników w portfelu kredytowym banków spółdzielczych w Polsce w latach 2012-2017 (\%)

\begin{tabular}{|c|c|c|c|c|c|}
\hline \multicolumn{2}{|c|}{ Wyszczególnienie } & \multirow{2}{*}{ ROA (X1) } & \multirow{2}{*}{$\begin{array}{c}\text { Współczynnik } \\
\text { kapitałowy (X2) }\end{array}$} & \multirow{2}{*}{ Tier-1 (X3) } & \multirow{2}{*}{$\begin{array}{l}\text { Udział kredytów } \\
\text { dla rolników (Y) }\end{array}$} \\
\hline kwartał & rok & & & & \\
\hline IV & 2012 & 1,2 & 13,8 & 13,1 & 30,6 \\
\hline I & 2013 & 1,0 & 14,0 & 13,1 & 29,9 \\
\hline II & 2013 & 0,9 & 13,8 & 13,6 & 29,8 \\
\hline III & 2013 & 0,9 & 14,2 & 13,4 & 29,9 \\
\hline IV & 2013 & 0,8 & 14,1 & 13,4 & 29,6 \\
\hline I & 2014 & 0,9 & 14,7 & 13,3 & 28,9 \\
\hline II & 2014 & 0,9 & 16,1 & 14,8 & 28,7 \\
\hline III & 2014 & 0,9 & 15,8 & 14,9 & 28,4 \\
\hline IV & 2014 & 0,8 & 15,8 & 14,7 & 28,4 \\
\hline I & 2015 & 0,8 & 15,6 & 14,9 & 27,5 \\
\hline II & 2015 & 0,7 & 15,9 & 14,8 & 27,9 \\
\hline III & 2015 & 0,7 & 15,6 & 14,5 & 29,0 \\
\hline IV & 2015 & 0,4 & 13,7 & 12,6 & 29,0 \\
\hline I & 2016 & 0,7 & 17,0 & 15,9 & 28,8 \\
\hline II & 2016 & 0,7 & 17,4 & 16,2 & 28,8 \\
\hline III & 2016 & 0,6 & 17,1 & 16,0 & 28,6 \\
\hline IV & 2016 & 0,5 & 17,1 & 16,0 & 28,2 \\
\hline I & 2017 & 0,8 & 17,0 & 16,0 & 28,1 \\
\hline II & 2017 & 0,7 & 17,5 & 16,5 & 28,1 \\
\hline
\end{tabular}

Źródło: opracowanie własne na podstawie informacji o sytuacji banków spółdzielczych i zrzeszających się w latach 2012-2017, http://www.knf.gov.pl/index.html, [dostęp: 31.10.2017] 
Tabela 2 zawiera obliczenia dotyczące współzależności statycznej między zmiennymi.

Tabela 2. Współczynniki korelacji między zmiennymi X1 i Y, X2 i Y oraz X3 i Y w Polsce_w latach 2012-2017

\begin{tabular}{|c|l|l|l|}
\hline Zmienne & X1-Y & X2-Y & X3-Y \\
\hline Współczynnik korelacji & 0,541 & $-0,713$ & $-0,688$ \\
\hline
\end{tabular}

Źródło: Opracowanie własne na podstawie Tabeli 1

W oparciu o przeprowadzone badanie można stwierdzić, że między rentownością aktywów a udziałem rolników w portfelu kredytowym w bankach spółdzielczych w Polsce w latach 2012-2017 współzależność statystyczna jest dodatnia o umiarkowanej sile, a dodatkowo wyznaczony współczynnik korelacji jest istotny statystycznie. Oznacza to, że wzrostowi udziału kredytów dla rolników w portfelu kredytowym banków spółdzielczych towarzyszy wzrost rentowności aktywów tych banków i odwrotnie, spadającemu znaczeniu w portfelu kredytowym kredytów dla rolników towarzyszy spadająca rentowność aktywów.

Z kolei między współczynnikami kapitałowymi opisującymi wypłacalność finansową banków a udziałem rolników w portfelu kredytowym w bankach spółdzielczych w Polsce w latach 2012-2017 współzależność statystyczna jest ujemna, co oznacza, że wzrostowi znaczenia kredytów dla rolników w portfelu kredytowym banków spółdzielczych w Polsce towarzyszy spadek współczynników kapitałowych i odwrotnie. Siłę tej korelacji można ocenić jako znacząca, przy czym wyznaczone współczynniki korelacji między zmiennymi nie są istotne statystycznie.

\section{Podsumowanie}

$\mathrm{Na}$ podstawie przeprowadzonych $\mathrm{W}$ pracy badań sformułowano następujące wnioski:

Wartość kredytów udzielonych rolnikom przez banki spółdzielcze w Polsce w latach 2012-2017 konsekwentnie wzrastała, jednak w tempie niższym od przyrostu należności od pozostałych grup klientów tych banków. Udział kredytów dla rolników w łącznym portfelu kredytowym w bankach spółdzielczych w Polsce wg stanu na koniec 2012 roku wynosił 30,6\%, natomiast na półrocze 2017 roku 28,1\%. Warto zwrócić uwage, że początkowo była to najważniejsza grupa kredytobiorców pod względem udziału w wolumenie kredytowym, jednak już od 2013 roku zostali wyprzedzeni przez MSP i ta relacja została zachowana do końca badanego okresu. Powyższe wnioski potwierdzają hipotezę (H1), że systematycznie spada udział kredytów dla rolników w łącznym portfelu należności od klientów niefinansowych banków spółdzielczych w Polsce.

Poziom rentowności aktywów segmentu banków spółdzielczych w Polsce w całym badanym okresie zmniejszał się. Na początku badanego okresu wskaźnik ROA przyjmował wartość $1,2 \%$, by na koniec przyjąć poziom $0,8 \%$, choć najniższą wartość wskaźnika zanotowano w IV kwartale 2015, wówczas oscylował on wokół 0,4\%. Jednocześnie zmniejszał się udział rolników jako grupy kredytobiorców. Pomiędzy udziałem kredytów dla rolników w portfelu kredytowym banków spółdzielczych w 
Polsce w latach 2012-2017 a rentownością aktywów w badanym okresie wystapiła korelacja dodatnia o umiarkowanej sile. Zatem przedstawione wnioski potwierdzają hipotezę $(\mathrm{H} 2)$.

W całym badanym okresie wypłacalność sektora banków spółdzielczych mierzona łącznym współczynnikiem kapitałowym, jak i współczynnikiem Tier-1, pozostawała na wysokim poziomie. Łączny współczynnik kapitałowy banków spółdzielczych w Polsce w latach 2012-2017 przyjmował wartości w zakresie od 13,8\% do 17,5\%, w współczynnik kapitałowy Tier-1 odpowiednio: od 13,1\% do 16,5\%. Należy zauważyć, że w całym badanym okresie wartość współczynników wypłacalności była powyżej wymaganego przepisami prawa minimum. Między udziałem rolników w portfelu kredytowym a łącznym współczynnikiem kapitałowym i współczynnikiem kapitałowym Tier-1 wystąpiła korelacja ujemna, a nie jak zakładano - korelacja dodatnia, w związku z czym hipoteza (H3) nie została potwierdzona.

Uwzględniając przytoczone wyniki badań, można stwierdzić, że rolnicy pozostają dla banków spółdzielczych bardzo ważną grupą klientów i to niezależnie od tego, że udział kredytów od tej grupy klientów banków spółdzielczych w łącznym wolumenie kredytowym zmniejsza się. Z uwagi na relacyjny charakter bankowości na poziomie spółdzielczym, lokalny charakter działania takich banków, relatywnie wysoką jakość portfela kredytowego dla rolników (wielokrotnie lepszą w porównaniu do portfela kredytów MSP i przedsiębiorców indywidualnych) i zaobserwowaną korelację między udziałem kredytów dla rolników w całkowitym portfelu kredytowym a rentownością aktywów banków spółdzielczych, powinny one rozważyć podjęcie zintensyfikowanych działań w celu zwiększenia znaczenia rolników jako kredytobiorców.

\section{Bibliografia}

Informacja o sytuacji banków spółdzielczych i zrzeszających się w latach 2012-2017, http://www.knf.gov.pl/index.html

Kata R.: Bankowa obsługa rolnictwa w kontekście zmian modelu funkcjonowania bankowości spółdzielczej w Polsce, Roczniki Naukowe Stowarzyszenia Ekonomistów Rolnictwa i Agrobiznesu, t. XVII, z. 4, Warszawa 2015

Kata R.: Korzystanie z usług bankowych przez rolników indywidualnych w Polsce, Journal of Agrobusiness and Rural Development, nr 4(22), Uniwersytet Rzeszowski, Rzeszów 2011

Kata R.: Relacje rolników $\mathrm{z}$ instytucjami $\mathrm{w}$ aspekcie finansowania gospodarstw ze źródeł zewnętrznych, w: Konkurencyjność podmiotów rynkowych, red. D. Kopycińska, Uniwersytet Szczeciński, Szczecin 2009

Kata R.: Kredyty bankowe w strukturze zewnętrznych źródeł finansowania rolnictwa w Polsce, Zeszyty Naukowe SGGW w Warszawie, Problemy Rolnictwa Światowego, t. XXIII, Warszawa 2009

Kozak S.: Ewolucje strukturalne w sektorze banków spółdzielczych w latach 1996-2011, Zeszyty Naukowe Uniwersytetu Przyrodniczo-Humanistycznego w Siedlcach, nr 96, Siedlce 2013

Nowakowska-Krystman A., Kublik B.: Strategia rozwoju sektora polskich banków spółdzielczych, w: Perspektywy rozwoju bankowości spółdzielczej w Polsce, red. M. Stefański, Wyższa Szkoła Humanistyczno-Ekonomiczna we Włocławku, Włocławek 2009

Rosa A.: Korzystanie $\mathrm{z}$ usług bankowych przez rolników pomorza środkowego, Roczniki Naukowe Stowarzyszenia Ekonomistów Rolnictwa i Agrobiznesu nr 6, z. 6, Politechnika Koszalińska , Koszalin 2016 
Siudek T.: Wpływ kredytów rolniczych udzielanych przez banki spółdzielcze na rozwój rolnictwa w Polsce, Zeszyty Naukowe SGGW w Warszawie, Ekonomika i Organizacja Gospodarki Żywnościowej, Warszawa 2008

Siudek T.: Banki spółdzielcze jako instytucje kredytujące rozwój rolnictwa i obszarów wiejskich w Polsce, Zeszyty Naukowe Akademii Rolniczej we Wrocławiu nr 540, Wrocław 2006

Snarski P.: Metody pomiaru satysfakcji klientów bankowych wykorzystywanych do analizy konkurencyjności banków, Oficyna Wydawnicza Politechniki Białostockiej, Białystok 2012

Szelagowska A.: Współczesna bankowość spółdzielcza, CeDeWu Sp. z o.o., Warszawa 2012

Utzig M.: Korzystanie z rynku depozytowo-kredytowego przez rolników w Polsce, Roczniki Ekonomii Rolnictwa i Rozwoju Obszarów Wiejskich, t. 99, z. 4, Warszawa 2012

Woźniewska G.: Analiza potencjału konkurencyjnego banku spółdzielczego - zarys koncepcji, Annales Universitatis Mariae Curie-Skłodowska, Sectio H Oeconomia, UMCS, Lublin 2010

\section{Summary}

The main objective of the article is to assess of the importance of farmers as debtors and the influence of this group of clients on the profitability and security of cooperative banks in Poland between 2012-2017. The analysis was based on quarterly data between December 2012 and June 2017 (19 observations).

The following hypotheses were introduced: the share of farmers in the credit structure of cooperative banks decreases (H1), the decrease in the farmers' credit share in the total number of credits in cooperative banks lowers their profitability measured by the ROA index, and the correlation magnitude is at least moderate (H2), the decreased share of farmers in the credit portfolio of cooperative banks is positively correlated with the level of the total solvency ratio and Tier-1 capital ratio, and this correlation is at least of moderate magnitude (H3).

The conducted research allows to conclude that: the share of credits for farmers in the total credit portfolio of cooperative banks in Poland is decreasing. It is correlated with the level of assets profitability, the correlation is positive, and its magnitude is at least moderate. Simultaneously, it is negatively correlated with the level of Tier-1 capital ratio. Hence, only two out of three hypotheses have been verified.

Key words: cooperative banks, farmers, profitability, solvency

Informacje o autorze:

\section{Dr Artur Stefański}

Wyższa Szkoła Bankowa w Poznaniu, Wydział Finansów i Bankowości

Ul Powstańców Wielkopolskich 5

61-895 Poznań

e-mail: artur.stefanski@wsb.poznan.pl

ORCID: 0000-0002-7235-337X. 